\title{
Medium Term Analysis of Technical and Allocative Efficiency in Romanian Farms Using FADN Dataset
}

\author{
Nicola GALLUZZO* \\ Association of Geographical and Economic Studies of Rural Areas (ASGEAR) \\ Via Salaria per L'Aquila, 76 scala A 02100 Rieti Italy \\ *)Corresponding author, e-mail: asgear@libero.it \\ BulletinUASVM Horticulture 74(1) / 2017 \\ Print ISSN 1843-5254, Electronic ISSN 1843-5394 \\ DOI:10.15835/buasvmcn-hort:12645
}

\begin{abstract}
The Farm Accountancy Data Network (FADN) is an annual survey established by the European Union in order to estimate the economic impact of the Common Agricultural Policy on farmers. Lots of scholars have investigated the technical, economical and allocative efficiency using a non-parametric approach such as the Data Envelopment Analysis (DEA). Romanian farms belonging to the Farm Accountancy Data Network dataset have highlighted modest levels of technical efficiency compared to the average European value investigated by other authors. The purpose of this study was to assess using the DEA approach technical, economic and allocative efficiency in Romanian farms belonging to the FADN dataset from 2007 to 2012. Findings have pointed out an increase of technical efficiency compared to previous studies carried out in transition economies such as Poland, Slovenia and Bulgaria, as a consequence of an intense generational turn over in Romanian characterized by a younger high skill and qualified farmers' generation. Poor land capital, in terms of utilized agricultural areas, and a low level of investments in new technologies, were the main downsides in Romanian farms; hence, the National Rural Development Plan should improve financial subsides in order to get better modest agrarian plots in farms scattered in the Romanian rural space.
\end{abstract}

Keywords: Common Agricultural Policy, Data Envelopment Analysis, rural development, subsistence farms.

\section{INTRODUCTION}

Since 1965, the European Union by the Council Regulation number 79 has established an annual analysis on a sample of farmers in order to assess the impact of the Common Agricultural Policy towards farmers in all European Countries called Farm Accountancy Data Network (FADN). FADN is an annual survey in 80,000 farms which covers a population of about $5,000,000$ farms located in the European Union and almost $90 \%$ of the European utilized agricultural area (European Commission, 2014).

According the European Commission and Eurostat, in Italy and in Romania are concentrated one third of the European farms even if, in Romania more than $90 \%$ of them have got an utilized agricultural area lower than 5 hectares with a significant decrease in the last decade by more $25 \%$ of workers in the primary sector (Festuccia, 2013).

In Romania, there are 3,629,660 small family farms dispersed in rural areas as reported by the recent Eurostat data published in 2013. Usually, the poorer is the agricultural area and farm size the lower is the level of efficiency and farmer's income (Lund and Hill, 1979; Alvarez and Arias, 2004; Galluzzo, 2013). Despite this conceptual theoretical framework, other authors in some European countries have pointed out as small farms, due to a simplified traditional organization and management of cropping system, have had better results in terms of technical and economic efficiency than large farms and corporate agrarian enterprises (Gorton and Davidova, 2004); hence, 
the farm size impacts partially on the level of technical efficiency (Nowak et al., 2015; Galluzzo, 2013; 2015).

The size of capital land, financial subsidies allocated by the European Union to small farms as well as the level of skills and education of farmers have acted directly on the level of technical and economic efficiency in several European agrarian enterprises (Latruffe et al., 2005; Bojnec and Latruffe, 2013; Manevska-Tasevska, 2013; Galluzzo, 2013). Findings in transition economies in new comer member states of the European Union located in East of Europe, such as Bulgaria, Poland, Slovenia, have stressed as family farms have had the highest levels of efficiency, which is directly correlated and influenced by other variables such as the gender of farmers, the human capital and by the agricultural specialization of farms (Mathijs and Vranken, 2001).

In many European countries, a lot of studies have investigated on a sample of farms, using either the FADN dataset or alternatively few specific investigations carried out on a sample of farms located in different nations, the impact of financial subsidies allocated by the pillar two and by the first pillar of the Common Agricultural Policy (CAP) on farmer's income. The purpose of these latter studies was to assess main relationships and quantitative connections among the variables farm size, cropping specialization, productive system, payments disbursed by the CAP and technicaleconomic efficiency in farms (Bojnec and Latruffe 2008; Bielik and Rajcaniova 2004; Latruffe and Nauges, 2014).

Financial subsidies allocated by the II pillar of the Common Agricultural Policy, in terms of direct payments and aids paid with the purpose to strengthen the rural development and the multifunctionality in the primary sector, have had an irreplaceable role in all European countries in reducing socio-economic marginalization, rural emigration and territorial disparities (Galluzzo, 2015). In particular, in the new comer member state of the EU as Romania and also Bulgaria, subsidies disbursed by the Single Area Payment Scheme, in the context of the National Rural Development Plan 2014-2020, have raised farmer's profitability and consequently the level of technical and economic efficiency, lessening farm net income decline (Galluzzo, 2015).
Since the middle 2000s, in Romania, such as in all European countries, there has been a shrinking of financial subsidies allocated by the CAP with the consequence to emphasize the dichotomy in terms of technical and allocative efficiency among large size and small size farms. This economic and streamlined gap is rather obvious because some financial supports partially coupled to the farm size, the level of agrarian production and to the productive specialization correlate directly with technical and economic efficiency. Furthermore, small farms are more vulnerable to the rural emigration from the countryside than the large size farms taking less advantage of European Union subsidies compared to agrarian enterprises with a large endowment in land capital (Cionga et al., 2008). Modest economic-financial and technicaleconomic efficiency performances in Romanian farms are due to poor levels of investments in land capital and in new technologies labor saving; hence, financial supports allocated by the CAP are pivotal for a socio-economic survival of Romanian agrarian enterprises by improving technical efficiency in farms (Burja and Burja, 2010).

In general, the European Size Unit (ESU), stated by the European Union in its Commission Decision no. 377 published in 1985, defines the level of subsistence of farms in function of their level of farmer's income. Farms above 1 ESU are considered subsistence farms. More than 70\% of Romanian farms has an agricultural utilized surface close to 1 hectare, then they can be set in this subsistence cluster because of their poor level of farm's income (Giurca, 2008). According to this author, Romanian government had to plan its National Rural Development Plan in function of specific features of small family farms in order to get better the level of efficiency in almost 3 million subsistence farms throughout an increase of disposable financial resources. In particular, those financial aids, allocated by the second pillar of the CAP, have tailored specific measures of rural development aimed at stimulating the farm's productive diversification.

A crescent number of Romanian farms has pointed out a rise of younger farmers or rather a growth of a newly generation of wealth creation farmers able to enhance the level of efficiency in using the financial subsidies allocated by the European Union, increasing economic performances and mitigating ageing problems in 
the Romanian countryside (Tudor and Alexandri, 2015). These authors, in fact, have assessed a direct correlation between the high level of skill and knowledge in young farmers and the growth of technical efficiency. In general, a growth of intangible investments and capital in skill and knowledge as proposed in 1980 by Lockheed, Jamison and Lau improves the level of technical and economic efficiency. According to these latter authors, an higher level of farmer's education and an efficient use of new technologies in farms in a perspective of market oriented management increases the level of farm net income (Tudor and Alexandri, 2015) and consequently the technical and economic efficiency.

The purpose of this analysis was to assess by a quantitative model the technical, economic and allocative efficiency over six-year time (20072012) in a sample of Romanian farms belonging to the Farm Accountancy Data Network (FADN) located in 8 Romanian regions.

FADN is a secondary statistical source of information with the aim to inform farmers and other stakeholders about the role and impact of political decisions realized by the Common Agricultural Policy to farms and the impact of financial subsidies allocated by the CAP towards European farmers. Several criticisms have been addressed to the FADN. This latter survey creates an unnatural threshold with the purpose of categorizing farms, specifically small enterprises, in function of their level of efficiency in a commercial viewpoint (Roger, 2014) without taking into account others aspects in an holistic assessment of the Common Agricultural Policy.

Recent findings in the estimation of efficiency in many European farms belonging to the FADN dataset have pointed out as technical efficiency is uncorrelated to the variable agricultural areas as it depends upon its own intrinsic features such as the quality of soil and other intangible variables (Nowak et al., 2015).

In literature, more studies have investigated the efficiency in Romanian farms using time series of the Farm Accountancy Data Network dataset pointing out as the majority of farms are under the average value of technical efficiency calculated in all European farms belonging to the Farm Accountancy Data Network dataset (Burja, 2011). The main determinants affecting the efficiency in farms are technical capital, land capital, farm size, typology of farm's ownership and investments as estimated in other European countries (Slovenia, Poland, Italy) characterized by small farms (Nowak et al., 2015; Galluzzo, 2013). In Romanian rural areas, regional disparities, consequence of a low level of agrarian capital used by farms, are increasing with the effect of broadening the socioeconomic dichotomy among Romanian agrarian regions (Burja, 2012; Burja, 2011).

\section{MATERIALS AND METHODS}

In literature, there are two methodologies to study the efficiency: a parametric or deterministic approach, which needs a specific function of production and other parametric variables, and a non-parametric model or DEA (Data Envelopment Analysis). The Data Envelopment Analysis uses observed inputs and outputs and it does not require a specific mathematical function of production. The level of efficiency, whose optimal value equal to 1 or $100 \%$, is an index of efficient performance which is assessed in function of the distance from the frontier of an hypothetical function of production (Coelli et al., 2005; Bielik and Rajcaniova 2004; Picazo-Tadeo et al., 2011; Charnes et al., 1978). In a non-parametric model, some deviations from the frontier of the function are not efficient and they are not connected to errors thus, technical efficiency is described as an ability of farmers in maximizing the output minimizing used inputs or vice versa (Bojnec and Latruffe 2008).

The efficiency in this paper has been estimated by a non-parametric model applied to specific assumptions in a constant return to scale (CRS) input oriented model (Farrel 1957; Battese 1992; Coelli 1996) using PIM-DEA and Deap 2.1. software on the Romanian FADN dataset. In this paper, the input variables have been formed by specific crop costs, such as fertilizers and crop protection costs, farming overheads, land capital, financial subsidies allocated by the CAP; the output variable has been formed by farmer's net income.

The purpose of DEA linear programming approach is to minimize in a multiple-output model the used multiple-input in each farm or unit of production, that is simply a ratio of efficiency between the variable input $\left(\mathrm{x}_{\mathrm{ijo}}\right)$ and produced output $\left(\mathrm{y}_{\mathrm{rjo}}\right)$ and $\mathrm{u}_{\mathrm{r}}, \mathrm{v}_{\mathrm{i}}$ are the weights to assess the solution of the efficiency problem, written in a mathematical model as (Coelli et al., 2005): 
$\operatorname{maxh}=\sum_{\mathrm{r}} \mathrm{u}_{\mathrm{r}} \mathrm{y}_{\mathrm{rjo}} / \sum_{\mathrm{i}} \mathrm{V}_{\mathrm{i}} \mathrm{x}_{\mathrm{ijo}}$

$\mathrm{h}$ is the minimizing of multiple-input model or the maximization of produced output in the multiple-output method.

s.t.:

$\sum_{\mathrm{r}} \mathrm{u}_{\mathrm{r}} \mathrm{y}_{\mathrm{rij}} / \sum_{\mathrm{i}} \mathrm{v}_{\mathrm{i}} \mathrm{x}_{\mathrm{ij}} \leq 1$

$\mathrm{j}=0,1, \ldots . . . \mathrm{n}$ (for all $\mathrm{j}$ )

$\mathrm{u}_{\mathrm{r}}, \mathrm{v}_{\mathrm{i}} \geq 0$

In term of productivity, if there are two Decision Making Units (DMUs), such as A and B, producing two levels of output such as $\mathrm{y}_{\mathrm{a}}$ or $\mathrm{y}_{\mathrm{b}^{\prime}}$, using a specific quantity of input $x_{a}$ and $x_{b}$, the productivity is a simple ratio $\mathrm{y}_{\mathrm{a}} / \mathrm{x}_{\mathrm{a}}$ and $\mathrm{y}_{\mathrm{b}} / \mathrm{x}_{\mathrm{b}}$. The non-parametric linear model throughout the Data Envelopment Analysis has been introduced for the first time in 1978 (Charnes et al., 1978) and it is useful to estimate the efficiency in each Decision Making Units minimizing the different level of used input or maximizing the produced output (Hadad et al., 2007; Doyle and Green 1994).

The aim of a non-parametric input oriented model, used in this research, is to minimize in a multiple-output model the multiple-input in each farm that being a ratio of efficiency implies lots of possible solutions. Findings in this approach have highlighted in which Romanian regions are concentrated technical and economic inefficient farms and which input, such as crops costs, total overheads costs and financial subsides allocated by the CAP, are not efficient and they need to be improved.

The value of efficiency (h) should be greater than 0 and lower to 1 or $100 \%$, even if a value close to 1 or $100 \%$ represents the optimal value of efficiency. If $h$ is not efficient or rather its value is close to 1 or $100 \%$, the Decision Making Unit might

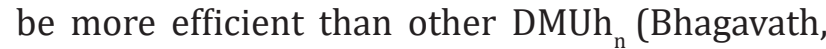
2009). Whether $\mathrm{h}$ is under 1 or $100 \%$ (DMU1 for example) there are lots of efficient units DMUn that are more efficient than DMU1 with different weights more favourable than others in the process of minimization of inputs or maximization of output, generating a problem in an adequate choice of which weights are the best in increasing the efficiency (Bhagavath, 2009; Charnes et al., 1962).

To solve this negative aspect is fundamental to transform the model by a linear programming methodology as proposed by Charnes et al. (1962)

maximising the output (Bhagavath 2009; Galluzzo, 2013):

$\max \mathrm{h}=\sum_{\mathrm{r}} \mathrm{u}_{\mathrm{r}} \mathrm{y}_{\text {rio }}$

s.t. dual variable

$\sum_{\mathrm{i}} \mathrm{V}_{\mathrm{i}} \mathrm{X}_{\mathrm{ijo}}=100 \%$ which is the function $\mathrm{h}$ to maximize or $\mathrm{Z}_{\mathrm{o}}$

$\sum_{\mathrm{r}} \mathrm{u}_{\mathrm{r}} \mathrm{y}_{\mathrm{rjo}}-\sum_{\mathrm{i}} \mathrm{v}_{\mathrm{i}} \mathrm{x}_{\mathrm{ijo}} \leq 0 \quad$ with $\mathrm{j}=0,1, \ldots \mathrm{n}$ (for all $\mathrm{j}$ ) $\lambda_{\mathrm{j}}$

$-\mathrm{v}_{\mathrm{i}} \leq-\varepsilon \quad \mathrm{i}=0,1, \ldots . \mathrm{m}$ and $\varepsilon$ is a positive value $\mathrm{s}_{\mathrm{i}}{ }^{+}$

$\mathrm{u}_{\mathrm{r}} \leq-\varepsilon \quad \mathrm{r}=0,1, \ldots \mathrm{t}$ and $\varepsilon$ is a positive value $\mathrm{s}_{\mathrm{r}}{ }^{-}$

The variables $v_{i}$ and $u_{r}$, which are some solutions of the maximization problem, have to be greater or equal than a small positive quantity $\varepsilon$ fundamental in avoiding that any input or output can be ignored in assessing the efficiency (Bhagavath 2009; Charnes et al., 1962). In the dual problem, it is important to consider a dual variable in each constraint in the primary model (Charnes et al., 1978) able to classify and discriminate each DMU using the super efficiency called A\&P model (Andersen and Petersen 1993). In mathematical terms, according to these authors, the solution of the dual model in every constraint in the primal model is written as a minimization of the maximization function (Bhagavath 2009; Charnes et al., 1962):

$\min 100 \mathrm{Z}_{\mathrm{o}}-\varepsilon \sum_{\mathrm{i}} \mathrm{S}_{\mathrm{i}}^{+}-\varepsilon \sum_{\mathrm{r}} \mathrm{S}_{\mathrm{r}}^{-}$

s.t.:

$\sum_{\mathrm{j}} \lambda_{\mathrm{i}} \mathrm{X}_{\mathrm{ij}}=\mathrm{x}_{\mathrm{ij} 0} \mathrm{Z}_{\mathrm{o}}-\mathrm{s}_{\mathrm{i}}^{+} \mathrm{i}=0,1, \ldots \mathrm{m}$

$\sum_{\mathrm{j}} \lambda_{\mathrm{i}} \mathrm{x}_{\mathrm{rj}}=\mathrm{y}_{\mathrm{ri} 0}+\mathrm{s}_{\mathrm{r}}^{-} \quad \mathrm{r}=0,1, \ldots . \mathrm{t}$

$\lambda_{\mathrm{i},} \mathrm{s}_{\mathrm{i}}^{+}, \mathrm{s}_{\mathrm{r}}^{-} \geq 0$

Conventionally, $\lambda_{\mathrm{j}}$ are shadow prices able to reduce the efficiency in each unit lower than 100 which is the highest positive level of efficiency. In general, a positive value of shadow prices in the dual model identifies in a peer group every inefficient units (Bhagavath 2009; Charnes et al., 1962).

\section{RESULTS AND DISCUSSION}

Focusing the attention on the level of farm's income, Romanian farms belonging to the FADN dataset have been predominately classified as medium-low economic size because their average value is close to 9 European Size Unit (ESU) as 
Tab. 1. Descriptive statistics of Romanian farms belonging to the FADN Dataset

\begin{tabular}{cccccc}
\hline Variable & Observation & Mean & Std. deviation & Min & Max \\
\hline Economic size (ESU) & 48 & 9.34 & 2.52 & 5.3 & 17.2 \\
\hline Utilised Agricultural Areas (ha) & 48 & 10.30 & 3.11 & 5.43 & 15.97 \\
\hline Cereals area (ha) & 48 & 5.70 & 2.47 & 2.74 & 10.92 \\
\hline Forage area (ha) & 48 & 2.44 & 1.79 & 0.06 & 6.15 \\
\hline Dairy cows (n ${ }^{\circ}$ & 48 & 1.54 & 0.42 & 0.75 & 2.48 \\
\hline${\text { Sheep and goats }\left(\mathrm{n}^{\circ}\right)}^{\text {Pig }^{\circ} \mathrm{n}^{\circ} \text { ) }}$ & 48 & 2.48 & 1.17 & 0 & 4.53 \\
\hline Source: our elaboration on data http://ec.europa.eu/agriculture/rica/database/database_en.cfm & 0.26 & 2.3 \\
\hline
\end{tabular}

Tab. 2. Descriptive economic statistics of Romanian farms belonging to the FADN Dataset

\begin{tabular}{|c|c|c|c|c|c|}
\hline Variable & Observation & Mean & Std. deviation & Min & Max \\
\hline $\begin{array}{l}\text { Farm net income } \\
(€)\end{array}$ & 48 & $5,381.02$ & $3,157.79$ & 457 & 17,681 \\
\hline $\begin{array}{l}\text { Total subsides on } \\
\text { crops (€) }\end{array}$ & 48 & 97.97 & 379.65 & 0 & 2,407 \\
\hline $\begin{array}{c}\text { Environmental } \\
\text { subsidies }(€)\end{array}$ & 48 & 29.66 & 53.39 & 0 & 280 \\
\hline $\begin{array}{c}\text { Less Favoured } \\
\text { Subsidies (LFA in } € \text { ) }\end{array}$ & 48 & 15.83 & 30.66 & 0 & 123 \\
\hline $\begin{array}{c}\text { Total supports on rural } \\
\text { development }(€)\end{array}$ & 48 & 79.83 & 131.69 & 0 & 576 \\
\hline $\begin{array}{c}\text { Single area payment } \\
(€)\end{array}$ & 48 & 861.81 & 432.17 & 260 & 1,860 \\
\hline
\end{tabular}

proposed by the European Union in its Commission Decision no. 377 published in 1985. Findings in terms of utilized agricultural areas have pointed out uneven surface among Romanian farms which fluctuates in a range from 5 to 15 hectares predominately cultivated with cereals and forage crops (Tab. 1). The main cattle-breeding are set up by dairy cows, whose average value is close to 1.5 bovine animal for each farm belonging to the FADN dataset and in general it does not exceed 3 units. In contrast, the average livestock number of sheep and goats and pigs is respectively 2.48 and 0.91 livestock units which is equivalent, using specific transforming coefficients, to 24 sheep and 3 pigs per farms.

The level of farm net income has pointed out as many Romanian farms are part of semisubsistence and subsistence farms, under the value of $3 \mathrm{ESU}$, which take positive advantages from financial subsides allocated by the European Union as subsidies on crops and by Single Area
Payment Scheme (Tab. 2). On the contrary, financial aids disbursed towards disadvantaged rural areas are less significant than environmental subsidies.

The variable Single Area Payment Scheme (SAPS) correlates directly, using Spearman's rank correlation coefficient at a level of $5 \%$ of significance, both to the total financial subsidies allocated by the second and first pillar of the CAP with a value of 0.51 and also to the direct costs tightly linked to the productive activity with a correlation coefficient equal to 0.42 . This implies the higher are costs of production, due to larger agricultural areas in Romanian farms, the higher are the level of SAPS payments disbursed by the European Union.

The lowest level of technical efficiency has been assessed in 2007 in Romanian farms located in South-East region even if, over the time of investigation, there has been an increase of efficiency (Tab.3). In contrast, Romanian farms in South-West Oltenia and in Bucharest-Ilfov regions 
Tab. 3. Technical efficiency over six-year time in Romanian farms part of the FADN Dataset

\begin{tabular}{cccccccc}
\hline \multirow{2}{*}{ Region } & \multicolumn{7}{c}{ year } \\
\cline { 2 - 8 } & 2007 & 2008 & 2009 & 2010 & 2011 & 2012 & $\begin{array}{c}\text { Mean in } \\
\text { region }\end{array}$ \\
\hline North-East & 88.43 & 100.00 & 100.00 & 100.00 & 100.00 & 100.00 & 98.07 \\
\hline South-East & 9.15 & 100.00 & 100.00 & 100.00 & 100.00 & 100.00 & 84.86 \\
\hline South-Muntenia & 45.83 & 100.00 & 49.10 & 63.95 & 63.95 & 60.02 & 63.81 \\
\hline South-West-Oltenia & 100.00 & 100.00 & 100.00 & 100.00 & 100.00 & 100.00 & 100.00 \\
\hline West & 80.67 & 100.00 & 100.00 & 100.00 & 100.00 & 100.00 & 96.78 \\
\hline North-West & 72.01 & 100.00 & 100.00 & 100.00 & 100.00 & 100.00 & 95.34 \\
\hline Center & 66.59 & 67.20 & 76.38 & 100.00 & 100.00 & 92.93 & 83.85 \\
\hline Bucurest-Ilfov & 100.00 & 100.00 & 100.00 & 100.00 & 100.00 & 100.00 & 100.00 \\
\hline Mean for year & 70.34 & 95.90 & 90.69 & 95.49 & 95.49 & 94.12 & $\mathbf{9 0 . 3 4}$ \\
\hline Source: our elaboration on data http://ec.europa.eu/agriculture/rica/database/database_en.cfm & & & &
\end{tabular}

Tab. 4. Economic efficiency over six-year time in Romanian farm part of the FADN Dataset

\begin{tabular}{cccccccc}
\hline \multirow{2}{*}{ Region } & \multicolumn{7}{c}{ year } \\
\cline { 2 - 8 } & 2007 & 2008 & 2009 & 2010 & 2011 & 2012 & Mean in region \\
\hline North-East & 34.96 & 32.22 & 76.53 & 70.15 & 70.15 & 53.63 & 56.27 \\
\hline South-East & 2.84 & 29.66 & 51.70 & 63.47 & 63.47 & 72.78 & 47.32 \\
\hline South-Muntenia & 15.87 & 20.88 & 35.66 & 38.46 & 38.46 & 36.06 & 30.90 \\
\hline South-West-Oltenia & 43.57 & 31.26 & 64.02 & 87.01 & 87.01 & 100.00 & 68.81 \\
\hline West & 24.23 & 23.62 & 76.26 & 100.00 & 100.00 & 81.07 & 67.53 \\
\hline North-West & 20.34 & 42.34 & 100.00 & 90.37 & 90.37 & 76.18 & 69.93 \\
\hline Center & 9.89 & 20.62 & 42.52 & 71.69 & 71.69 & 62.39 & 46.47 \\
\hline Bucurest-Ilfov & 100.00 & 100.00 & 35.56 & 64.69 & 64.69 & 41.07 & 67.67 \\
\hline Mean for year & 31.46 & 37.58 & 60.28 & 73.23 & 73.23 & 65.40 & $\mathbf{5 6 . 8 6}$ \\
\hline Source: our elaboration on data http://ec.europa.eu/agriculture/rica/database/database_en.cfm & & &
\end{tabular}

have underlined the highest values of technical efficiency. Findings have pointed out significant fluctuations comparing the outcomes of technical efficiency both among Romanian regions and also over the years of investigation. South-Muntenia region has pointed out the lowest level of technical efficiency due to the poorest level of farm net income.

Focusing the attention on the variable economic efficiency, findings have pointed out in farms located in the South-East regions the poorest value in 2007; instead, farms in North-West Romanian region have stressed the highest level of economic efficiency (Tab.4). In general, with the exception of the year 2012, there has been in all Romanian regions an increase of economic efficiency with the unique exception of a significant drop of economic efficiency in the region of Bucharest-Ilfov.
Allocative efficiency and economic efficiency have stressed the poorest values in all investigated farms part of the FADN dataset. In general, farms located in West region have pointed out the highest level of allocative efficiency; conversely, farms in South-Muntenia have had the poorest level of allocative efficiency. In 2007, in Central Romanian regions it was possible to find out the lowest level of allocative efficiency, which is increased in average value over the time of investigation (Tab. 5).

The assessment of technical performances in terms of efficiency, using the DEA approach in the variable return to scale and in the constant return to scale approaches, has pointed out as farmers located in North-East, South-Muntenia, West, North-West and Center regions are positioned close to the frontier of efficiency function equal to $100 \%$ (Tab. 6). Two Romanian regions (South-East and 
Tab. 5. Allocative efficiency over six-year time in Romanian farms part of the FADN Dataset

\begin{tabular}{cccccccc}
\hline \multirow{2}{*}{ Region } & 2007 & 2008 & 2009 & 2010 & 2011 & 2012 & $\begin{array}{c}\text { Mean in } \\
\text { region }\end{array}$ \\
\cline { 2 - 8 } & 39.53 & 32.22 & 76.53 & 70.15 & 76.53 & 70.15 & 60.85 \\
\hline North-East & 31.06 & 29.66 & 51.70 & 63.47 & 51.70 & 63.47 & 48.51 \\
\hline South-East & 34.62 & 20.88 & 72.62 & 60.13 & 35.66 & 60.13 & 47.34 \\
\hline South-Muntenia & 43.57 & 31.26 & 64.02 & 87.01 & 64.02 & 87.01 & 62.82 \\
\hline South-West-Oltenia & 30.03 & 23.62 & 76.26 & 100.00 & 76.26 & 100.00 & 67.70 \\
\hline West & 28.24 & 42.34 & 100.00 & 90.37 & 100.00 & 90.37 & 75.22 \\
\hline North-West & 14.86 & 30.68 & 55.67 & 71.69 & 42.52 & 71.69 & 47.85 \\
\hline Center & 100.00 & 100.00 & 35.56 & 64.69 & 35.56 & 64.69 & 66.75 \\
\hline Bucurest-Ilfov & 40.24 & 38.83 & 66.55 & 75.94 & 60.28 & 75.94 & $\mathbf{5 9 . 6 3}$ \\
\hline Mean for year & & & & & &
\end{tabular}

Tab. 6. Comparing technical efficiency average over six-year time in Romanian farms part of the FADN Dataset

\begin{tabular}{lcccc}
\hline \multicolumn{1}{c}{ Region } & Constant Return & Variable Return & Sale & Type of return \\
& To Scale (CRS) & To Scale (VRS) & Efficiency & to scale \\
\hline North-East & 100.00 & 100.00 & 100.00 & - \\
\hline South-East & 93.10 & 100.00 & 93.10 & irs \\
\hline South-Muntenia & 100.00 & 100.00 & 100.00 & - \\
\hline South-West-Oltenia & 83.20 & 94.60 & 87.90 & irs \\
\hline West & 100.00 & 100.00 & 100.00 & - \\
\hline North-West & 100.00 & 100.00 & 100.00 & - \\
\hline Center & 100.00 & 100.00 & 100.00 & drs \\
\hline Bucurest-Ilfov & 90.50 & 100.00 & 100.00 & - \\
Mean & 95.80 & 99.30 & 96.40 & \\
irs stands for increasing return to scale; drs stands for decreasing return to scale \\
Source: our elaboration on data http://ec.europa.eu/agriculture/rica/database/database_en.cfm using Deap 2.1
\end{tabular}

South-West-Oltenia) have been the most efficient using the variable return to scale approach; hence, an increase of inputs, in terms of variable return to scale, improves the technical performances on farms. Farms located in Bucharest-Ilfov region have underlined a decreasing return to scale thus, an increase of input has reduced the level of produced output.

The appraisal of technical efficiency targets has pointed out the best results in BucharestIlfov and in South West Oltenia regions. Farmers working in these Romanian regions need a modest strengthening in financial subsidies allocated by the Common Agricultural Policy. Focusing the attention on the input analysis, findings have pointed out the need to reduce crop costs and farming overheads costs (Tab.7). Farms located in South Muntenia and in the Center regions have underlined over the time of investigation a decline of crop costs associated to a decrease of financial subsides allocated by the CAP in order to improve their technical and economic efficiency performances.

Comparing outcomes of technical efficiency to previous researches using a constant return to scale (CRS) input based approach, it emerges an increase of technical efficiency which in average value shifted from $74.7 \%$, as assessed by Nowak et al. in 2015 , to $90.34 \%$ as estimated in this research. Furthermore, this value of technical 
Tab. 7. Comparing targets of technical efficiency in crop costs, farming overhead costs and financial subsidies allocated by the CAP

\begin{tabular}{|c|c|c|c|c|c|c|c|c|c|}
\hline Region & $\begin{array}{c}\text { Specific } \\
\text { crop costs } \\
\text { hectare } \\
\text { Value } \\
(€)\end{array}$ & $\begin{array}{c}\text { Specific } \\
\text { crop costs } \\
\text { hectare } \\
\text { Target }(€)\end{array}$ & $\begin{array}{l}\text { Specific } \\
\text { crop costs } \\
\text { hectare } \\
\text { Gain }(\%)\end{array}$ & $\begin{array}{c}\text { Total } \\
\text { farming } \\
\text { overheads } \\
\text { Value } \\
(€)\end{array}$ & $\begin{array}{c}\text { Total } \\
\text { farming } \\
\text { overheads } \\
\text { Target } \\
(€)\end{array}$ & $\begin{array}{c}\text { Total } \\
\text { farming } \\
\text { overheads } \\
\text { Gain (\%) }\end{array}$ & $\begin{array}{c}\text { Single } \\
\text { Area } \\
\text { payment } \\
\text { Value } \\
(€)\end{array}$ & $\begin{array}{c}\text { Single } \\
\text { Area } \\
\text { payment } \\
\text { Target }(€)\end{array}$ & $\begin{array}{c}\text { Single } \\
\text { Area } \\
\text { payment } \\
\text { Gain (\%) }\end{array}$ \\
\hline $\begin{array}{l}\text { Bucurest- } \\
\text { Ilfov }\end{array}$ & 161.42 & 161.42 & 0.00 & $3,923.83$ & $3,923.83$ & 0.00 & $1,051.67$ & 1051.67 & 0.00 \\
\hline Center & 179.40 & 135.44 & -26.41 & $2,701.83$ & $1,554.31$ & -35.80 & 932.83 & 617.16 & -32.46 \\
\hline North-East & 172.69 & 148.79 & -12.64 & $1,389.67$ & $1,312.98$ & -7.33 & 585.83 & 564.09 & -8.36 \\
\hline North-West & 172.03 & 145.09 & -12.90 & $2,138.50$ & $1,739.43$ & -12.36 & 693.67 & 668.37 & -7.51 \\
\hline South-East & 157.83 & 134.67 & -15.14 & $2,604.50$ & $2,249.94$ & -15.59 & $1,114.67$ & $1,009.86$ & -15.86 \\
\hline $\begin{array}{c}\text { South- } \\
\text { Muntenia }\end{array}$ & 187.13 & 91.29 & -50.37 & $2,644.17$ & $1,227.29$ & -51.94 & 866.17 & 514.22 & -41.35 \\
\hline $\begin{array}{l}\text { South-West- } \\
\text { Oltenia }\end{array}$ & 166.82 & 166.82 & 0.00 & $1,580.00$ & $1,580.00$ & 0.00 & 542.33 & 542.33 & 0.00 \\
\hline West & 170.64 & 152.66 & $\begin{array}{l}-10.31 \\
\end{array}$ & $2,369.67$ & $2,202.56$ & -9.24 & $1,107.33$ & $1,056.92$ & -10.50 \\
\hline
\end{tabular}

efficiency has been higher than the same value of technical efficiency reported in all European countries (Nowak et al., 2015; Burja, 2011). Findings have reaffirmed the positive role of agrarian capital in terms of land surface and investments in new technologies labour savings, in increasing efficiency. Burja in 2012, using an output approach in the efficiency estimation instead of an input approach used in this paper, has pointed out a value of technical efficiency sensitive to the increase of inputs but it was lower than that assessed in this analysis.

Summing up, previous analysis carried out in Romanian farms have stressed a level of technical efficiency equal to $74.70 \%, 83.90 \%$ and 59.90 \% (Nowak et al., 2015, Burja, 2012; Burja, 2011). These findings have been far below the value of technical efficiency estimated in this paper. A positive increase in the level of technical economic and allocative efficiency has been found in farms located in South Muntenia region. Farmers in Central region and close to the Romanian administrative capital of Bucharest have pointed out the best results in terms of technical efficiency even if it is declined over the time of investigation as a consequence of economic recession which involved all Romanian farms.

\section{CONCLUSIONS}

Findings have pointed out a value of technical efficiency higher than the outcomes assessed in other studies carried out in Romania by Burja in 2011, which were close to $84 \%$ in constant return to scale and $92 \%$ in variable return to scale. For the future, it is important to strengthened the positive role of the financial subsides allocated by the European Union in implementing the level of efficiency in Romanian farms. In fact, the increase of efficiency as demonstrated in this paper is imputable to the generational turn over using the financial supports allocated by the CAP. Furthermore, financial subsidies disbursed by the second pillar of the CAP have allowed besides a generational turnover of farmers, an implementation of training activities and a diffusion of technical assistance programs (Tudor and Alexandri, 2015; Bacescu-Carbunaru and Condruz-Bacescu, 2014) with direct impacts on the technical efficiency. According to these authors, the Common Agricultural Policy has been pivotal towards Romanian farmers prearranging them in facing with the new challenges of globalization in a perspective of environment and landscape protection (Tudor and Alexandri, 2015; BacescuCarbunaru and Condruz-Bacescu, 2014). 
The methodology based on the constant return to scale approach has highlighted an increase of technical efficiency which in average value shifted from $74.7 \%$ as assessed by Nowak et al. in 2015 to $90.34 \%$ as estimated in this research (Burja, 2011). Over the time of investigation, Romanian farms belonging to the FADN dataset have had levels of technical and economic efficiency lower than results assessed in previous research, corroborating the importance for farmers of some actions finalized in increasing the land capital endowment, in improving crop specialization and in strengthening investments in new technologies. Furthermore, Romanian farms have been very sensitive to the economic recession during the time of investigation with significant fluctuations in technical and allocative efficiency.

To better the efficiency in Romanian farms, it is important to support financially, in the National Rural Development Plan, small subsistence farms with the purpose to implement firstly their agrarian capital and secondly strengthening the level of investments in new technologies and innovative skills and knowledge, in particular towards younger farmers, bearing in mind as an increase of technical and economic efficiency improves the socio-economic protection of rural space and its environment.

\section{REFERENCES}

1. Alvarez A, Arias C (2004). Technical efficiency and farm size: a conditional analysis. Agricultural Economics 30(3): 241-250

2. Andersen P, Petersen N (1993). A procedure for ranking efficient units in data envelopment analysis. Management Science 39(10): 1261-1264.

3. Bacescu-Carbunaru A, Condruz-Bacescu M (2014). Objectives of the agricultural and rural development strategy of Romania. Competitiveness of Agro-Food and Environmental Economy 57.

4. Battese GE (1992). Frontier production functions and technical efficiency: a survey of empirical applications in agricultural economics. Agricultural Economics 7: 185208.

5. Bhagavath V (2009). Technical Efficiency Measurement by Data Envelopment Analysis: An Application in Transportation. Alliance Journal of Business Research. Available at www.ajbr.org/. Accessed 2015 Oct. 01.

6. Bielik P, Rajcaniova M (2004). Scale efficiency of agricultural enterprises in Slovakia. Agric. Econ. Czech 50(8): 331-335.
7. Bojnec S, Latruffe L (2008). Measures of farm business efficiency. Industrial Management \& Data Systems 108(2): 258-270.

8. Bojnec S, Latruffe L (2013). Farm size, agricultural subsidies and farm performance in Slovenia. Land Use Policy 32: 207-217.

9. Burja C (2012). Determinants of the agricultural productivity growth among Romanian regions. Annales Universitatis Apulensis Series Oeconomica 14(1): 217225.

10. Burja C, Burja V (2010). Financial analysis of the agricultural holdings viability in Romania in the European context. Annales Universitatis Apulensis Series Oeconomica 12(1):, 63-71.

11. Burja V (2011). Regional disparities of agricultural performance in Romania. Annales Universitatis Apulensis Series Oeconomica 13(1):115-121.

12. Charnes A, Cooper WW, Kortanek K. (1962). Duality, Haar programs, and finite sequence spaces. Proceedings of the National Academy of Sciences of the United States of America 48(5):783-786.

13. Charnes A, Cooper WW, Rhodes E (1978). Measuring the Efficiency of Decision Making Units. European Journal of Operational Research 2(6): 429-444.

14. Cionga C, Luca L, Hubbard C. (2008). The Impacts Of Direct Payments On Romanian Farm Income: Who Benefits From The Cap?. In $109^{\text {th }}$ EAAE Seminar proceedings "The CAP after the Fischler Reform: National Implementations, Impact Assessment and the Agenda for Future Reforms" Viterbo, 20-21 November 2008, Available at www. ageconsearch.umn.edu/bitstream/44840/2/4.1.4 Lucian.pdf. Accessed 2015 Oct. 01

15. Coelli $\mathrm{T}$ (1996). Recent developments in frontier modelling and efficiency measurement. Australian Journal of agricultural economics 39(3): 219-245.

16. Coelli TJ, Rao DSP, O’Donnell CJ, Battese GE (2005). An introduction to efficiency and productivity analysis. Springer Science \& Business Media, 349 p.

17. Doyle J, Green R (1994). Efficiency and cross-efficiency in DEA: derivations, meanings and uses. Journal of Operational Research Society 45(5): 567-578.

18. European Commission Agriculture and Rural Development, (2014). Concept of FADN. Available at www. ec.europa.eu/agriculture/rica/concept_en.cfm. Accessed 2015 Oct. 01.

19. Farrell MO (1957). The measurement of productive efficiency. Journal of Royal Statistical Society 120: 253281.

20. Festuccia A (2013): In Italia e Romania la metà delle aziende agricole UE. Pianeta PSR, 17. Available at www. pianetapsr.it/flex/cm/pages/ServeBLOB.php/L/IT/ IDPagina/764. Accessed 2015 Oct. 01

21. Galluzzo N (2013). Farm dimension and efficiency in Italian agriculture: a quantitative approach. American Journal of Rural Development 1(2): 26-32.

22. Galluzzo N (2015). Analysis of impact of rural development subsides on cropping specialization in Bulgaria and Romania using FADN data. $150^{\text {th }}$ EAAE Seminar "The 
spatial dimension in analysing the linkages between agriculture, rural development and the environment", Edinburgh, UK, October 22-23 2015. Available at http:// ageconsearch.umn.edu. Accessed 2015 Nov. 15.

23. Giurca D (2008). Semi-Subsistence Farming-Prospects for the Small Romanian Farmer to Choose between a "Way of Living" or Efficiency. Agricultural Economics and Rural Development 5(3-4): 215-230.

24. Gorton M, Davidova S (2004). Farm productivity and efficiency in the CEE applicant countries: a synthesis of results. Agricultural economics 30(1): 1-16.

25. Hadad Y, Friedman L, Hanani MZ (2007). Measuring efficiency of restaurants using the data envelopment analysis methodology. Computer modelling and New Technologies 11(4): 25-35.

26. Latruffe L, Balcombe K, Davidova S, Zawalinska K (2005). Technical and scale efficiency of crop and livestock farms in Poland: does specialization matter?. Agricultural economics 32(3): 281-296.

27. Latruffe L, Nauges C (2014). Technical efficiency and conversion to organic farming: the case of France. European Review of Agricultural Economics 41(2): 227253.

28. Lockheed ME, Jamison T, Lau LJ (1980). Farmer education and farm efficiency: A survey. Economic development and cultural change, 29(1): 37-76.
29. Lund PJ, Hill PG (1979). Farm Size, Efficiency And Economies Of Size. Journal of Agricultural Economics 30(2): 145-158.

30. Manevska-Tasevska G (2013). Farmers' knowledge attributes contribute to attaining higher farm technical efficiency: a transition economy case. The Journal of Agricultural Education and Extension 19(1):7-19.

31. Mathijs E, Vranken L (2001). Human capital, gender and organisation in transition agriculture: measuring and explaining the technical efficiency of Bulgarian and Hungarian farms. Post-communist economies 13(2):171187.

32. Nowak A, Kijek T, Domanska K (2015). Technical efficiency and its determinants in the European Union agriculture. Agricultural Economics (Zemědělská Ekonomika) 61(6): 275-283.

33. Picazo-Tadeo AJ, Gómez-Limón JA, Reig-Martínez E (2011). Assessing farming eco-efficiency: a data envelopment analysis approach. Journal of environmental management 92(4): 1154-1164.

34. Roger A (2014). 'Romanian Peasants' into 'European Farmers'? Using Statistics to Standardize Agriculture. Development and Change 45(4):732-752.

35. Tudor MM, Alexandri C (2015). Structural Changes in Romanian Farm Management and their Impact on Economic Performances. Procedia Economics and Finance 22: 747-754. 